\title{
The Effect of Work Discipline on a Employee Performance (The Health Office Case Study of Tanimbar Island)
}

\author{
Edy Slamet Kelibulin', Sukri Palutturi ${ }^{2}$, Muhammad Alwy Arifin², Indar', Yahya Thamrin ${ }^{3}$, \\ Stang $^{4}$, Suci Rahmadani ${ }^{2}$ \\ ${ }^{1}$ Research Scholar, Magister Program Departement of Health Administration and Policy, Public Health \\ Hasanuddin University, ${ }^{2}$ Professor of Departement of Health Administration and Policy, Public Health \\ Hasanuddin University, ${ }^{3}$ Lecturer of Departement of Occupational Safety and Health, Public Health Hasanuddin \\ University, ${ }^{4}$ Professor of Department of Biostatistics, Public Health Hasanuddin University
}

\begin{abstract}
Employee performance is paramount in achieving goals. Employees will achieve work when they have the discipline and motivation to perform their job well. The purpose of this research is to analyze the effect of work discipline on the performance of employees of the Tanimbar islands district health office. This research uses a type of quantitative research and cross-sectional design. Data collection is done by observation, questionnaire, and document study. The samples in this study were 61 officers of the Health office of the Tanimbar Islands regency. A sampling of this research used total sampling. The collected data is processed using the Statistical Package for the Social Sciences program. The results showed the value of $\mathrm{P}=0,537$ means that there is no influence between the work discipline to the performance of employees of the District Health Office of Tanimbar Islands. Therefore, the health office of the Tanimbar Islands District needs to discipline employees through a better surveillance process.
\end{abstract}

Keywords: Work discipline, Performance, Employee, Health office

\section{Introduction}

Employee performance is paramount in achieving goals. Employees will achieve work when they have the discipline and motivation to perform their job well. It is the duty of a leader to apply working discipline and to motivate his subordinates in order to work in accordance with the intended purpose. Therefore, the leader must know the factors that affect the motivation of employee work so that employees ' performance increases. With high discipline and motivation, employees will perform their best tasks, so that the objectives that want to be achieved according to the plan. If a leader is unable to engage the discipline and motivation of employee work, the employee's performance will be decreased ${ }^{1}$.

\section{Correspondence Author:}

Edy Slamet Kelibulin

E-mail: edys.kelibulin@gmail.com
In achieving the success of an employee performance organization is a determining success in achieving its objectives. Good organizational performance is indispensable for realizing the vision and mission of an organization in the future. To get a performance assessment for employees need to be performed a performance evaluation called by performance assessment or performance appraisal ${ }^{2}$.

From the initial survey conducted at the Health office of the Tanimbar Islands, it can be noted that employees ' performance in the Health service department is still less good and affects the quality of work. It can be seen less accuracy in the completion of the instructed work so that the time needed in the completion of the work is getting longer. Another thing that we often find in the administration of the establishment and in other areas of duty is very slow in solving problems that occur in the field, one of which often lose mail on the subject of the letter is much needed to be archived to the service. Based on the explanation of the problem above how important 
role of working discipline in improving employee's performance.

\section{Materials and Method}

The type of research used is quantitative research with Cross Sectional Study Draft. The population in this research is the overall employee who works in the Tanimbar Islands Health Office (PNS, CPNS, and PPPK) does not include cleaning service and security as much as 61 people. The sampling technique in this study was used in total sampling where the number of samples was equal to the population. Data collection is obtained through interviews using data processing questionnaires conducted in computerised by using SPSS program. Data presented in narrative form, frequency distribution table accompanied by interpretation.

\section{Results}

The results showed the value of $\mathrm{P}=0,537$ means that there is no influence between the work discipline to the performance of employees of the District Health Office of Tanimbar Islands. Some results are presented in the tables below:

Table 1. Distribution of Respondents Based on Characteristics of Respondents Health Office Tanimbar Islands in $\mathbf{2 0 2 0}$

\begin{tabular}{|c|c|c|}
\hline Characteristics & Amount (n) & Percent (\%) \\
\hline $\begin{array}{l}\text { d. } \quad \text { Age (yr) } \\
18-30 \\
31-50 \\
>50\end{array}$ & $\begin{array}{l}10 \\
46 \\
5\end{array}$ & $\begin{array}{l}16.4 \\
75.4 \\
8.2\end{array}$ \\
\hline Total & 61 & 100.0 \\
\hline $\begin{array}{l}\text { e. } \quad \text { Gender } \\
\text { Male } \\
\text { Girl }\end{array}$ & $\begin{array}{l}29 \\
32\end{array}$ & $\begin{array}{l}47.5 \\
52.5\end{array}$ \\
\hline Total & 61 & 100.0 \\
\hline $\begin{array}{l}\text { f. Education } \\
\text { High school } \\
\text { Diploma } \\
\text { Bachelor degree) } \\
\text { Masters (S2) }\end{array}$ & $\begin{array}{l}11 \\
19 \\
28 \\
3\end{array}$ & $\begin{array}{l}18.0 \\
31.1 \\
45.9 \\
4.9\end{array}$ \\
\hline Total & 61 & 100.0 \\
\hline $\begin{array}{l}\text { g. Years of service } \\
<6 \text { years old } \\
6-10 \text { years } \\
>10\end{array}$ & $\begin{array}{l}5 \\
18 \\
3\end{array}$ & $\begin{array}{l}8.2 \\
29.5 \\
62.3\end{array}$ \\
\hline Total & 61 & 100.0 \\
\hline
\end{tabular}

Source: Primary Data, 2020 
Table 2: Variable Frequency Distribution of Work Discipline in the District Health Office. Tanimbar Islands in 2020

\begin{tabular}{|l|l|l|}
\hline The performance & Amount (n) & Percent (\%) \\
\hline Not good & 41 & 67.2 \\
\hline Good & 20 & 32.8 \\
\hline Total & 61 & 100.0 \\
\hline
\end{tabular}

Source: Primary Data, 2020

Table 2 shows that of the 61 respondents, there were 41 respondents with poor work discipline at 67.2 and 20 respondents with good work discipline at $32.8 \%$.

The effect of work discipline on Employee Performance

The bivariate relationship between work discipline and the performance of the Tanimbar Islands District Health Office employees can be seen in table 3 as follows

Table 3: The effect of work discipline on the Performance of the District Health Office. Tanimbar Islands in 2020

\begin{tabular}{|c|c|c|c|c|c|c|c|}
\hline \multirow{3}{*}{ Work Discipline } & \multicolumn{4}{|c|}{ Employee Performance } & \multirow{2}{*}{\multicolumn{2}{|c|}{ amount }} & \multirow{3}{*}{ Statistic test } \\
\hline & \multicolumn{2}{|c|}{ Not good } & \multicolumn{2}{|c|}{ Good } & & & \\
\hline & $\mathrm{n}$ & $\%$ & $\mathrm{n}$ & $\%$ & $\mathrm{n}$ & $\%$ & \\
\hline Not good & 32 & 52.5 & 14 & 23.0 & 46 & 75.4 & \\
\hline Good & 9 & 14.8 & 6 & 9.8 & 15 & 24.6 & \\
\hline Total & 41 & 67.2 & 20 & 32.8 & 61 & 100 & \\
\hline
\end{tabular}

Source: Primary Data, 2020

Table 3 shows that of the 15 respondents with a good working discipline of 6 respondents who have a good performance (9.8\%) and 9 Respondents had poor performance (14.8\%). While for poor working discipline amounted to 46 respondents as many as 14 respondents had a good performance (23.0\%) And 32 respondents had poor performance $(52.5 \%)$. Statistical test result by using Chi-square, but the chi-square test requirement is not fulfilled, then the value seen is the value of Fisher's exact value $\mathrm{P}=0,537$, because the value $\mathrm{p}>0.05$, then H0 accepted. This indicates that there is no influence between working discipline and employee performance at the Tanimbar Islands Health Office. 


\section{Discussion}

One form of measuring the performance of a good employee is to look at the discipline at work time. Time discipline here is interpreted as attitudes or behaviors that demonstrate adherence to working hours that includes the attendance and compliance of officers during working hours, employees perform tasks on time and right. It's supposed to work time discipline is applied based on consciousness to complete each job ${ }^{3}$.

The work discipline in this research is the effort to carry out its work activities in earnest (timely, obedient rules, according to the responsibilities given). The results of the analysis in table 3 showed that out of a total of 15 respondents with a good category of working discipline more respondents had less than 9 respondents (14.8\%). Meanwhile, from a total of 46 respondents with a less well-categorized working discipline, more respondents had a less than good performance amounting to 32 respondents $(52.5 \%)$. This is because there are certain points that tend not to be performed properly.

Statistical test result by using Chi-square, but the chi-square test requirement is not fulfilled, then the value seen is the value of Fisher's exact value $P=0,537$, because the value $\mathrm{p}>0.05$, then $\mathrm{H} 0$ accepted. This indicates that there is no relationship between working discipline and employee performance at the Tanimbar Islands District Health Office. The less-than-good working discipline reflects the lack of a person's responsibility for the task given to him. It is also evidenced by the many officers stating that they always come on time. Thus it can be concluded that it is about time discipline on the district health Tanimbar less good Research is not in line with the research conducted by Kasim et al., about the relationship of work discipline, leadership, training, and motivation to the performance of administration officers Abepura Papua Hospital in $2015^{4}$. One of the results of his research is the relationship between working discipline to the performance of the administrative officer of the Government Abepura Papua year 2015. The results of this study were not in line with research Panuluh and Gilang stating that discipline has a significant influence on work productivity ${ }^{5-10}$.

This research is also not in line with research Satria and Nio (2019) about the relationship of work discipline with the performance of the employees of PDAM Tirta
Jam Gadang Bukittinggi ${ }^{6}$. The working discipline indicator measured in the study is attendance, adherence to employment, adherence to working standards, high level of vigilance, and ethical work indicating a significant positive relationship between working discipline and performance in the employees of PDAM Tirta Jam Gadang, Bukittinggi City. That means the higher the employee's work discipline, the higher the performance of an employee. However, this research is in line with the conducted shows the simultaneous and partial work discipline has no effect on the employee's performance ${ }^{11-17}$.

\section{Conclusion}

The study concluded that there was no influence between working discipline and employee performance at the Tanimbar Islands Health Office with the value $\mathrm{P}=$ 0,537. District Health Office of Tanimbar Islands need to improve employee discipline through better supervision process.

Ethical Clearance- Taken fromUniversity ethical clearence committee

\section{Source of Funding- Self}

Conflict of Interest - Nil

\section{References}

1. Erisna, N. Hubungan Disiplin Dan Motivasi Kerja Dengan Kinerja Pegawai Pada Dinas Pendidikan Kabupaten Way Kanan. Jurnal Manajemen dan Bisnis, 2012; 2 .

2. Prasetiya, C. H. Analisis Faktor Yang Mempengaruhi Kinerja Perawat Di RSUD Sunan Kalijaga Demak. Jurnal Ilmu Dan Teknologi Kesehatan, 2017; 7.

3. Ginting, I. E. \& Wau, H. Hubungan Disiplin Kerja dengan Kinerja Pelayanan Kesehatan di Puskesmas Berastagi Kabupaten Karo. Jurnal Kesehatan Global, 2019; 2, 142-149.

4. Kasim, D., Rantetampang, A. \& Lumbantobing, H. Relationships of Work Discipline, Leadership, Training, and Motivation to Performance of Employees Administration Abepura Hospital Papua 2015. Journal of Sciences: Basic and Applied Research, 2016; 26, 154-164.

5. Panuluh, T. B. D. \& GILANG, A. Pengaruh 
Disiplin Kerja Terhadap Kinerja Karyawan Pada Pt Asuransi Ramayana Bandung. eProceedings of Management, 2019; 6.

6. Anwar Mallongi, Ezra Limbong, Furqaan Naiem, Hasanuddin Ishak, Syahrul Basri, Muh. Saleh, Aminuddin Syam, Laode Asrul. Health risk analysis of exposure to mercury $(\mathrm{Hg})$ and cyanide (CN) in Kayeli village communities Teluk Kayeli district Buru regency. Enfermería Clínica Volume 30, Supplement 4, June 2020, Pages 427-430

7. Eka sulistyawaty, Syafar, M., Daud, A., Arsunan Arsin, A., Mallongi, A., Werdyaningsih, E. Change of behavior of ODF through STBM Program in Cempaka Putih Village North Gorontalo Regency, Enfermeria ClinicaVolume 30, June 2020, Pages 396-398

8. Anwar Mallongi, Stang, Syamsuar, Muh Fajaruddin Natsir, Ratna Dwi Puji Astuti, Annisa Utami Rauf, Muhammad Rachmat, Abdul Muhithd, Potential ecological risks of mercury contamination along communities area in tonasa cement industry Pangkep, Indonesia. Enfermería Clínica., Volume 30, Supplement 4, June 2020, Pages 119-122

9. Satria, A. \& Nio, S. R. Hubungan Disiplin Kerja Dengan Kinerja Pada Karyawan PDAM Tirta Jam Gadang Bukittingi. Jurnal Riset Psikologi, 2019.

10. Setiawan, A. Pengaruh Disiplin Kerja dan Motivasi Terhadap Kinerjakaryawan Pada Rumah Sakit Umum Daerah Kanjuruhan Malang. Jurnal Ilmu Manajemen (JIM), 2013; 1.

11. Rosmala Nur, Siti Ika Fitrasyah, Anwar Mallongi, Women's Reactions and Health Disorders Caused by Abuse During the Pregnancy-Postpartum Period. Medico-legal Update, January-March 2020, Vol.20, No. 1
12. Rosmala Nur, Muh. Asep Dwitama, Muh. Fadly, Nurhaya S Patui, Sitti Radhiah, Elvaria Mantao, Anwar Mallongi,. The Culture and Age of First Marriage on Female Teenagers in West Marawola. Medico-legal Update, January-March 2020, Vol.20, No. 1

13. Kayame, R., Mallongi, A. Relationships between smoking habits and the hypertension occurrence among the adults of communities in paniai regency, Papua Indonesia. Indian Journal of Public Health Research and Development 2018; Volume 9, Issue 1, Pages 332-336

14. Birawida, A.B., Selomo, M., Mallongi, A. Potential hazards from hygiene, sanitation and bacterium of refill drinking water at Barrang Lompo island (water and food safety perspective) IOP Conference Series: Earth and Environmental Science 2018; Volume 157, Issue 1, Article number 012034

15. Russeng, S.S., Saleh, L.M., Virani, D., Latief, A.W.L., Mallongi, A. The investigation of the lactic acid change among employee of national electrical power plan. Indian Journal of Public Health Research and Development 2018; Volume 9, Issue 1, Pages 361-365

16. Darmawansyah, Said, M., Yunus, R., Palutturi, S. Increasing inpatient service quality of using Quality Function Deployment method in Nene Mallomo Hospital of Sidrap Regency, Indonesia. Indian Journal of Public Health Research and Development, 2018; Volume 9, Issue 4, Pages 287291

17. Mallongi, A.,Safiu, D., Amqam, H., Syam, A., Hatta, M., Sutarti, T., Abdul, M., Siyoto, S., Apollo., Modelling of $\mathrm{SO}_{2}$ and $\mathrm{CO}$ pollution due to industry PLTD emission Tello in 2 Makassar Indonesia. Journal of Engineering and Applied Sciences Volume 14, Issue 2, 2019, Pages 634-640 